\title{
Sociālās atbildības un kopīgās vērtības radīšanas aspekti: iesaistītās puses un cilvēkresursi
}

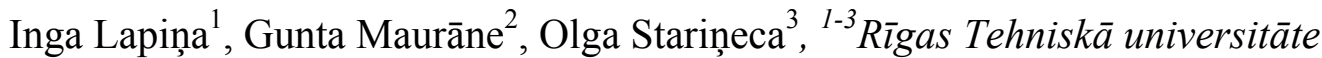

\begin{abstract}
Kopsavilkums. Pētījuma mērķis ir uzṇēmuma ilgtspējas veidošanas kontekstā raksturot un analizēt jēdzienus - iesaistītās puses, personāls un cilvēkresursi, korporatīvā sociālā atbildība un kopīgās vērtības radīšana, novērtēt šo jēdzienu kopīgās un atšķirīgās komponentes un savstarpējo saistību. Tiek pielietotas tādas pētnieciskās metodes kā zinātniskās literatūras analīze un sintēze, log̣iskā un salīdzinošã analīze. Pamatojoties uz veiktajiem teorētiskajiem pētījumiem un empīrisko analīzi, autores piedāvā jēdzienu attīstības apkopojumu un savu skatījumu uz minēto jēdzienu izpratni, īstenojot sociāli atbildīgu uzṇēmuma stratēǵiju vai kopīgās vērtības radīšanas pieeju.
\end{abstract}

Atslēgas vārdi: personāls, cilvēkresursi, iesaistītās puses, sociāli atbildīga stratēǵija.

\section{IEVADS}

Sociāli atbildīga pieeja Latvijas uzņēmumu vadībā kḷūst aizvien nozīmīgāka, galvenokārt vidēju un lielu uzņēmumu darbības kultūras veidošanā. Šo uzñēmumu kapacitāte atl̦auj domāt ne tikai par uzṇēmuma izdz̄̄vošanu, bet arī par savu resursu izmantošanu iesaistīto grupu (angḷu valodā stakeholders) interešu un vajadzību apmierināšanai.

Realizējot sociāli atbildīgu stratēǵiju vai īstenojot kopīgās vērtības radīšanas pieeju, uzn̄ēmumiem ir ne tikai jādefinēe savā darbībā iesaistītās grupas, bet arī jāatrod metodes, kas palīdzētu strādāt ar šīm grupām maksimāli efektīvi gan uzṇēmuma, gan sabiedrības interesēs. Sekojot mūsdienu sabiedrības, tirgus un uzṇēmumu vadības attīstības tendencēm, ir novērojama virzība uz atbildības un vērtību integrēšanu visdažādākajos procesos un jomās. Cilvēkresursi ir uzṇēmuma darbības viens no pamatelementiem un veiksmes faktoriem, kas bieži veido arī uzṇēmuma konkurētspējīgo priekšrocību. Tādējādi jēdzienu iesaistītās puses un cilvēkresursi izpratne ir īpaši svarīga, veidojot uzņēmuma attīstības stratēgiju.

Raksta ietvaros jēdziens „organizācija” tiek lietots plašākā nozīmēe, saprotot ar to gan uzṇēmumus, gan iestādes, gan nevalstiskās organizācijas. Analizējot jēdzienus iesaistītās puses, korporatīvā sociālā atbildība un kopīgās vērtības radīšana, lielāka uzmanība tiek pievērsta uzṇēmējdarbības videi, tādēl galvenokārt tiek izmantots jēdziens uzṇēmums.

Pētījuma mērkis ir uzñēmuma ilgtspējas veidošanas kontekstā raksturot un analizēt jēdzienus - iesaistîtās puses, personāls un cilvēkresursi, korporatīvā sociālā atbildība un kopīgās vērtības radīšana, novērtēt šo jēdzienu kopīgās un atšksirīgās komponentes un savstarpējo saistību.

Pētījums tiek balstīts uz zinātniskās literatūras analīzi un sintēzi, pielietojot log̣iskās un salīdzinošās analīzes metodi.

Jēdzienu - iesaistîtās puses un cilvēkresursi - analīze ir daḷa no plašāka pētījuma, kas aptver sociāli atbildīgas uzṇēmuma stratēgijas un vadības aspektus Latvijā.

\section{II.PERSONĀLS, CILVĒKRESURSI UN CILVĒKKAPITĀLS}

Organizācijas kā sistēmas darbojas un attīstās, pateicoties visu tās elementu mijiedarbībai. Kols G.A. (Cole G.A.) par organizācijas pamata komponentēm uzskata: mērḳus (misiju, stratēgiju, politiku), cilvēkus (viņu zināšanas, prasmes, kompetences, uztveri), tehnoloǵijas, struktūru un kultūru (dominējošās organizācijas vērtības, vadības stilu) [1].

G. Dāvidsone organizācijas elementus sakārto 4 grupās [2]:

- stratēǵija;

- organizācijas dizains, kuru veido struktūra, procesi un amati;

- cilvēki - viņu kompetences, motivācija, lojalitāte;

- organizācijas kultūra, kuru veido vērtības, līderības stils un attiecīibas.

Lai arī dažādu autoru darbos organizācijas elementu raksturojumā parādās atšksirības, tomēr visi autori atzīmē, ka organizācijas darbības pamatā ir iesaistītie cilvēki, kuru darbības tiek apzināti vadītas un koordinētas organizācijas izvirzīto mērķu sasniegšanai.

Laika gaitā ir mainījusies gan attieksme pret organizācijā nodarbinātiem cilvēkiem, gan jēdzieni, kādi tiek izmantoti šo cilvēku apzīmēšanai.

Sākotnēji organizācijās nodarbinātos cilvēkus uzskatīja par darba resursiem, galveno uzmanību pievēršot cilvēka spējām veikt noteiktas funkcijas, uzdevumus un darbus.

20. gs. sākumā, augot un palielinoties organizācijām, pieaugot darbinieku neapmierinātībai, nostiprinoties arodbiedrībām un palielinoties valsts ietekmei darbinieku un darba devēju attiecībās, pakāpeniski notika arī akcentu maiña no uzdevumu vadīšanas uz cilvēku vadīšanu. Arvien plašāk organizācijā nodarbināto cilvēku apzīmēšanai tika izmantots jēdziens ,personāls".

20. gs. 60. gados saistībā ar zinātnes sasniegumu un jaunu tehnologiju ieviešanu mainījās darbaspēka daba: darbiniekiem bija nepieciešams augstāks izglītības līmenis, atšksirīgas prasmes un iemaņas. Pieauga darbinieku vēlme piedalīties lēmumu pien,emšanā. Rezultātā aktualizējās jēdziens ,„cilvēka kapitāls" (angḷu valodā human capital).

Cilvēka kapitāla teorija, kuras izveidotāji Šulcs T. (Schultz T.W.) un Bekers H. (Becker G.S.) saṇēma Nobela prēmiju, uzskatīja, ka darba devēja investīcijas darbinieku apmācībā un attīstībā ir ne tikai pel̦nas gūšanas līdzeklis, bet arī darbinieku piesaistǐšanas un noturēšanas līdzeklis. Tas ir īpaši svarīgi tāpēc, ka cilvēka kapitāls atšksirīibā no citiem kapitāla veidiem nepieder organizācijai, bet pašam darbiniekam. Darbinieki paši var lemt, kā izmantot savas spējas, laiku un spēkus [3]. 
ASV veiksmīgi pārnēma vispārējās kvalitātes vadīšanas principus no Japānas, atz̄̄stot, ka darbinieki ir svarīgs organizācijas resurss - cilvēkresurss (angḷu valodā human resources). ASV 20.gs. 80. gados tika izveidota cilvēkresursu vadības koncepcija. Tā nebija tikai formāla nosaukuma maiņa, bet izrietēja no attieksmes maiņas pret organizācijā nodarbinātajiem cilvēkiem.

21. gs. gan zinātniskajā, gan profesionālajā literatūrā, gan pašās organizācijās joprojām tiek izmantoti visi minētie jēdzieni: personāls, cilvēkresursi, cilvēkkapitāls. Taču dažādi autori šajos jēdzienos ietver atškirīīgu saturu.

Vraits P.M. (Wright P.M.) un līdzautori cilvēkresursus definē kā „cilvēkkapitāla kopumu, kurš ir firmas kontrolē un ir tiešās nodarbinātības attiecībās ar firmu" [4].

Gomez-Meija L.R. (Gomez-Mejia L.R.) ar līdzautoriem uzskata, ka cilvēkresursi ir „cilvēki, kuri strādā organizācijā (saukti arī par personālu)" [5].

Alans Praiss (Price A.) uzskata, ka organizācijas līmen̄̄ cilvēku resursi ir organizācijā nodarbinātie cilvēki un vinu cilvēkkapitāls, kurš ir izmantojams uzṇēmējdarbībā [6].

Jau pieminētie Šulcs T. un Bekers H. uzskata, ka cilvēkkapitāls ir vērtīgas īpašības (zināšanas, prasmes, motivācija), kuras var attīstīt ar attiecīgu ieguldījumu palīdzību. Investīcijas cilvēkkapitālā var būt apmācība, profesionālā pieredze, veselības aizsardzība, ǵeogrāfiskā mobilitāte. Ieguvums no investīcijām personālā ir līdzvērtīgs ieguvumam no investīcijām materiālajā sfērā [3].

S.A. Snels (Snell S.A.) un D.V. Bolanders (Bohlander G.W.) uzskata, ka „cilvēkkapitāls ir indivīdu prasmes, iemaņas un spējas, kurām ir ekonomiska vērtība organizācijā" [7].

Arī Latvijas profesionāḷu, pētnieku un grāmatu autoru vidū nav vienprātības minēto jēdzienu lietošanā.

G. Dāvidsone darbiniekus uzskata par stratēǵiski nozīmīgu organizācijas resursu un potenciāla avotu. Taču cilvēku kā resursu avota izmantošana organizācijās ir sarežǵīta. Darbinieki paši par sevi automātiski nerada vērtību. Vērtību rada cilvēku ieguldījums - darbā izmantotās zināšanas, prasmes, motivācija [2].

L.R. Dombrovska kā resursus, kas atrodas darba devēja rīcībā, lai varētu sasniegt izvirzītos mērķus, min finansiālos resursus, informācijas resursus un cilvēkresursus. Cilvēkresursi ir personāls un tā veiktspēja. Savukārt veiktspēju veido darbinieka kompetences (zināšanas, prasmes, pieredze, personības īpašības) un vēlme tās izmantot (motīvi un vērtības) [8].

L.R. Dombrovska savā grāmatā jēdzienu kapitāls skaidro kā bagātîbu, kas atrodas apgrozībā un dod labumu. Viṇa piedāvā jēdzienu cilvēkresursu kapitāls: „tie ir cilvēkresursi, viṇu uzkrātais kapitāls (zināšanas, prasmes) un viņos ieguldītie finansiālie līdzekḷi, reizināti ar personāla vēlmi un iespējām strādāt" [8]. Tādējādi autore uzskatāmi parāda kopīgo un atšksirīgo minētajos jēdzienos, kā arī šo jēdzienu savstarpējo saistību.

I. Vorončuka organizācijā nodarbināto cilvēku apzīmēšanai lieto jēdzienu personāls [9], bet I. Ešenvalde - gan jēdzienu personāls, gan jēedzienu cilvēkresursi, lietojot tos kā sinonīmus [10].
Autores secina, ka, lai aprakstītu cilvēku nozīmīgumu organizācijās, pētnieki un jomas profesionāḷi joprojām izmanto vairākus jēdzienus. Jēdzieni personāls, cilvēkresursi, cilvēkkapitāls, intelektuālais kapitāls u.c. parāda, ka cilvēki ir tie, kas nodrošina organizācijas sasniegumus (līdztekus citiem resursiem: naudas, materiālajiem un informācijas resursiem). Dal̦a autoru savos darbos lieto kādu vienu no minētajiem jēdzieniem, citi lieto šos jēdzienus kā sinonīmus, vēl citi meklē atšksirības starp jēdzieniem.

Vairāki autori atzīmēe, ka cilvēkresursi var būt ilgtspējīgas konkurētspējīgās priekšrocības potenciālais avots uzn̦ēmumā. Noturīgu konkurētspējīgo priekšrocību var sasniegt tikai tad, ja organizācijai ir cilvēku resursi, kurus nevar imitēt konkurenti [4].

Noslēdzot jēdzienu personāls, cilvēkresursi un cilvēkkapitāls analīzi, autores secina, ka, runājot par organizācijā nodarbinātajiem cilvēkiem, galvenokārt tiek uzsvērtas viṇu zināšanas, prasmes, pieredze un vēlme šo potenciālu ieguldīt darba procesā organizācijas mērḳu sasniegšanā. Tādējādi cilvēki, neatkarīgi no tā, kā tie tiek dēvēti organizācijā (personāls, darbinieki vai cilvēkresursi), ir kā organizācijai piederīga daḷa jeb viena no uzṇēmuma darbībā iesaistītām pusēm.

Organizācijas vadības vēlme un spēja vadīt šos cilvēkus atbildīgi un orientējot uz kopīgu vērtību radīšanu, raksturo un nosaka uzņēmuma attīstības stratēgiju un attieksmi pret pārējām iesaistītajām pusēm, kuras tiks analizētas turpmāk.

\section{IESAISTĪTĀS PUSES JEB GRUPAS}

1963. gadā Stenfordas pētniecības institūts pirmo reizi oficiāli lietoja jēdzienu, ,iesaistītās puses” (angl̦u valodā stakeholder) mūsdienu nozīmē kā ,grupas, bez kuru atbalsta organizācijas pārtrauktu savu eksistenci” [11]. 20.gs. 80.gados R.E. Frīmans (Freeman R. E.) izveidoja un formulēja iesaistīto pušu teoriju (angḷu valodā stakeholder theory). 1983.gadā R.E. Frīmans un D.L. Rīds (Reed D.L.) iesaistītās puses definēja „kā jebkuras identificējamas grupas vai indivīdi, no kuriem ir atkarīga organizācijas turpmākā izdzìvošana" [11].

1984.gadā R.E. Frīmans savā grāmatā publicēja klasisko, visbiežāk citēto, iesaistīto pušu definīciju: ,iesaistītās puses ir ikviena grupa vai indivīds, kas var ietekmēt vai ietekmē organizācijas mērķu sasniegšanu" [13].

Iesaistīto pušu teorija vai iesaistīto pušu pieeja organizācijas stratēǵiskajā vadīšanā paredz izstrādāt un realizēt tādu organizācijas stratēǵiju, kas apmierinātu iesaistīto pušu intereses. Šāda stratēgija nodrošinātu organizācijas panākumus ilgtermiņā. Vēlāk R.E. Frīmana iesaistīto pušu definējumu pieñēma un attīstīja tālāk arī citi zinātnieki [14].

A.F. Alkhafaji (Alkhafaji A.F.) 1989.gadā piedāvāja attiecināt iesaistìto pušu jēdzienu tikai uz tām grupām, par kurām organizācija ir atbildīga [11].

1995.gadā T. Donaldsons (Donaldson T.) un L. Prestons (Preston L.) atzīmēja, ka ,iesaistītās puses ir personas vai grupas, kurām ir likumīgas intereses korporatīvo aktivitāšu procedūras vai struktūras aspektos. Iesaistītās puses identificē pēc viṇu interesēm uzṇēmumā vai arī uzṇēmumam ir kādas 
atbilstošas funkcionālas intereses attiecībā uz šīm ieinteresētajām pusēm" [15].

M.B.E. Klarksons (Clarkson M.B.E.) iesaistītās puses raksturo kā personas vai grupas, kurām pagātnē, tagadnē vai nākotnē ir īpašumtiesības, tiesības vai intereses uzņēmumā un/vai tā aktivitātēs (vai arī tās pretendē uz šīm tiesībām). Šīs tiesības vai intereses var rasties savstarpējo darījumu rezultātā vai uzṇēmuma darbības rezultātā, un tās var būt tiesiskas vai morālas, individuālas vai kolektīvas. Iesaistītās puses, kurām ir vienādas intereses, prasības vai tiesības, apvieno vienā grupā. [16]

S.E. Džeksons (Jackson S.E.) ar līdzautoriem savā grāmatā, līdzīgi kā M.B.E. Klarksons, raksturoja iesaistītās puses kā „indivīdus vai grupas ar interesi, tiesībām vai īpašuma tiesībām organizācijā un tās aktivitātēs jeb darbībā" [17].

R.E. Frīmans savā grāmatā „Stratēgiskā vadīšana: iesaistīto pušu pieeja" 1984.gadā izveidoja organizācijas iesaistīto pušu karti. Katrai no identificētajām grupām ir ne tikai nozīme organizācijas panākumu sasniegšanā, bet arī ieinteresētība šo panākumu sasniegšanā. Visām iesaistītajām pusēm ir vienāda līmeņa nozìme un ieinteresētība [13].

Sākotnēji R.E. Frīmans izdalīja 11 iesaistîtās puses [13]:

- ipašnieki (owners);

- darbinieki (employees);

- klienti, pircēji (customers);

- vietējās sabiedriskās organizācijas (local community organisations);

- $\quad$ piegādātāji (suppliers);

- konkurenti (competitors);

- valdība (government);

- masu informācijas līdzeklii (media);

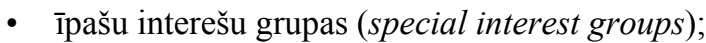

- patērētāju tiesību aizstāvji (consumer advocates);

- apkārtējās vides aizstāvji (environmentalists).

T. Donaldsons (Donaldson T.) un L. Prestons (Preston L.) 1995. gadā izveidoja iesaistīto pušu modeli, kurā visām iesaistītajām pusēm ir vienāda pozịcija attiecībā pret organizāciju. Visas personas vai grupas, kurām ir leǵitīmas (pamatotas) intereses, iesaistās uzņēmumā, lai gūtu labumus, un nevienai no tām nav priekšrocību attiecībā pret citu grupu [15]. Šajā modelī ir iekḷautas 8 iesaistītās puses [15]:

- investori (investors);

- darbinieki (employees);

- klienti (customers);

- kopienas (communities);

- valdības (governments);

- profesionālās asociācijas (trade associations);

- politiskās grupas (political groups);

- piegādātāji (suppliers).

Jau minētais M.B.E. Klarksons iesaistîtās puses iedala primārajās un sekundārajās. Primārās grupas ir iesaistītās puses, bez kuru nepārtrauktas līdzdalības uzṇēmums nevarētu izdzīvot. Starp uzņēmumu un primārajām iesaistītajām pusēm ir augsta savstarpējā atkarība. Tipiskas primārās grupas ir akcionāri un investori, darbinieki, klienti un piegādātāji, valdība un kopienas. Sekundārās grupas ir iesaistîtās puses, kuras ietekmē uzṇēmumu vai uzṇēmums ietekmēs tās, bet kuras nav iesaistītas uzṇēmuma tiešajā darbībā un kurām nav tik būtiskas nozīmes uzņēmuma izdzīvošanā. Tipiskas sekundārās grupas ir masu informācijas līdzekḷi un īpašu interešu grupas [16].

2007.gadā R.E. Frīmans ar līdzautoriem savā grāmatā pilnveido savu sākotnējo iesaistīto pušu karti, uzskatāmi parādot to sadalījumu primārajās un sekundārajās iesaistītajās pusēs (sk. 1.att.).

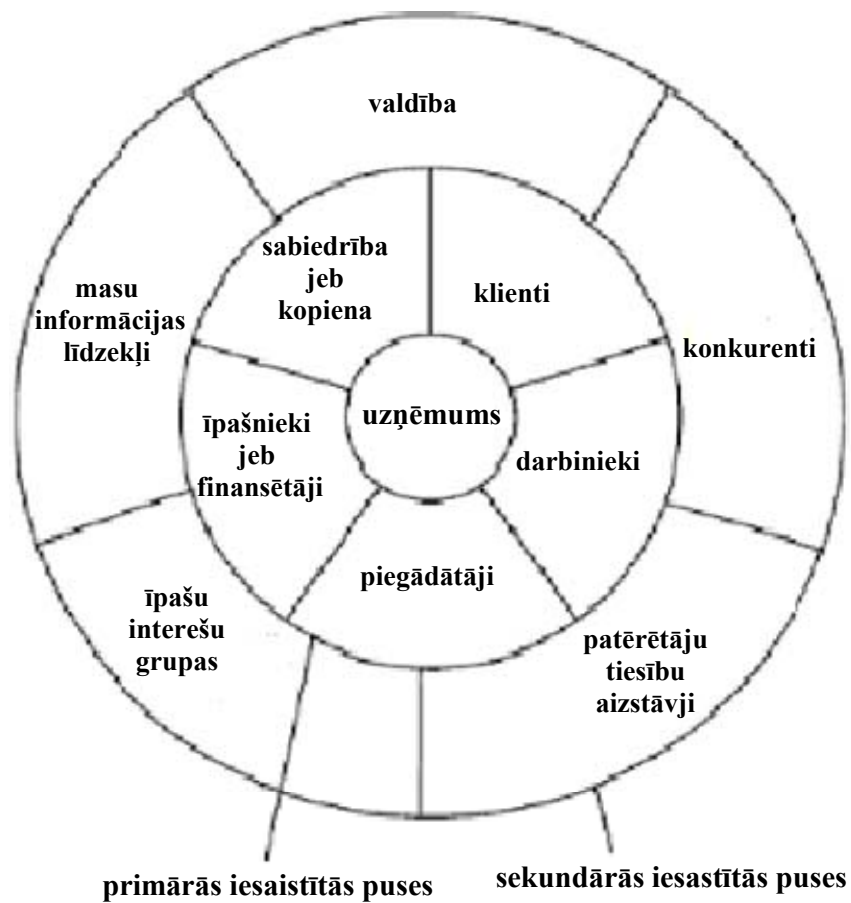

1.att. Iesaistīto pušu divu līmeṇu karte [18].

R.E. Frīmans ar līdzautoriem formulēja divas pieejas iesaistīto pušu definēšanā: šaurāko pieeju un plašāko pieeju. Viṇuprāt, šaurākā nozīmē iesaistītās puses ir tās grupas, bez kuru atbalsta bizness nebūtu dzīvotspējīgs. Šīs grupas ir primārās iesaistītās puses (klienti, darbinieki, piegādātāji un īpašnieki jeb finansētāji, sabiedrība jeb kopiena). Plašākā nozīmē iesaistītās puses ir grupas vai indivīdi, kas var ietekmēt vai ietekmē organizācijas mērķu sasniegšanu. Šādā dalījumā primārās iesaistītās puses papildina sekundārās iesaistītās puses (masu informācijas līdzekḷi, valdība, konkurenti, patērētāju tiesību aizstāvji, īpašu interešu grupas) un iesaistīto pušu spektrs ir ļoti plašs. Sekundārās iesaistītās puses ietekmē veidu, kādā tiek radīta vērtība primārajām iesaistītajām pusēm [18].

Latvijas profesionāļi, pētnieki un grāmatu autori jēdziena stakeholder apzīmēšanai izmanto dažādus jēdzienus: ietekmes puses [19], iesaistītās puses [20], ieinteresētās puses [21]. Šie trīs jēdziena tulkojumi ir visizplatītākie dažādos avotos latviešu valodā.

I. Kukule ietekmes grupas raksturo kā cilvēku grupas, kuras ietekmē uzṇēmuma darbība, aktivitātes, produkti un pakalpojumi un/vai, kam ir ietekme uz uzņēmumu [19].

Latvijas Biznesa konsultantu asociācijas (LBKA) definējumā iesaistītās puses ir visas uzņēmuma darbībā 
ieinteresētās puses gan tā iekšienē, gan ārpusē - visi, kuri tajā piedalās, un visi, kurus š̄ darbība ietekmē. Tie var būt: uzñēmuma akcionāri jeb īpašnieki, darbinieki un to gímenes, klienti, biznesa partneri, arodbiedrības, valsts institūcijas, nevalstiskās organizācijas, vietējā sabiedrība, masu informācijas līdzekḷi [20].

Piemēram, uzñēmuma Cemex ilgtspējīgas stratēǵijas viena no sastāvdal̦ām ir sadarbība ar ieinteresētajām pusēm. Cemex ieinteresētās puses ir tie cilvēki un grupas, kas ietekmē uzñēmuma darbību vai kurus savukārt skar uzṇēmuma darbība. Tie ir [21]:

- uzņēmuma cilvēki (darbinieki, apakšuzņēmēji un viņu gimenes),
- kopienas (vietējā sabiedrība, ieskaitot pašvaldības un nevalstiskās organizācijas),

- sadarbības partneri (piegādātāji, klienti, izplatītāji, investori),

- sabiedrība (nevalstiskās organizācijas, nacionālās valdības un regulatori, universitātes un masu saziņas līdzekḷi).

$\breve{S}_{\overline{1}}$ pētījuma ietvaros autores lieto tulkojumu ,iesaistītās puses", uzskatot, ka ne vienmēr organizācijas darb̄̄bā iesaistîtās puses ir arī ieinteresētas tās darbībā, kā arī to ietekmes iespējas un intereses ir l̦oti atšķirīgas.

Dažādu autoru viedokḷi par to, kādas grupas veido uzṇēmumā iesaistītās puses, apkopoti 1.tabulā.

1. TABULA

IESAISTĪTĀS PUSES (AUTORU VEIDOTA TABULA)

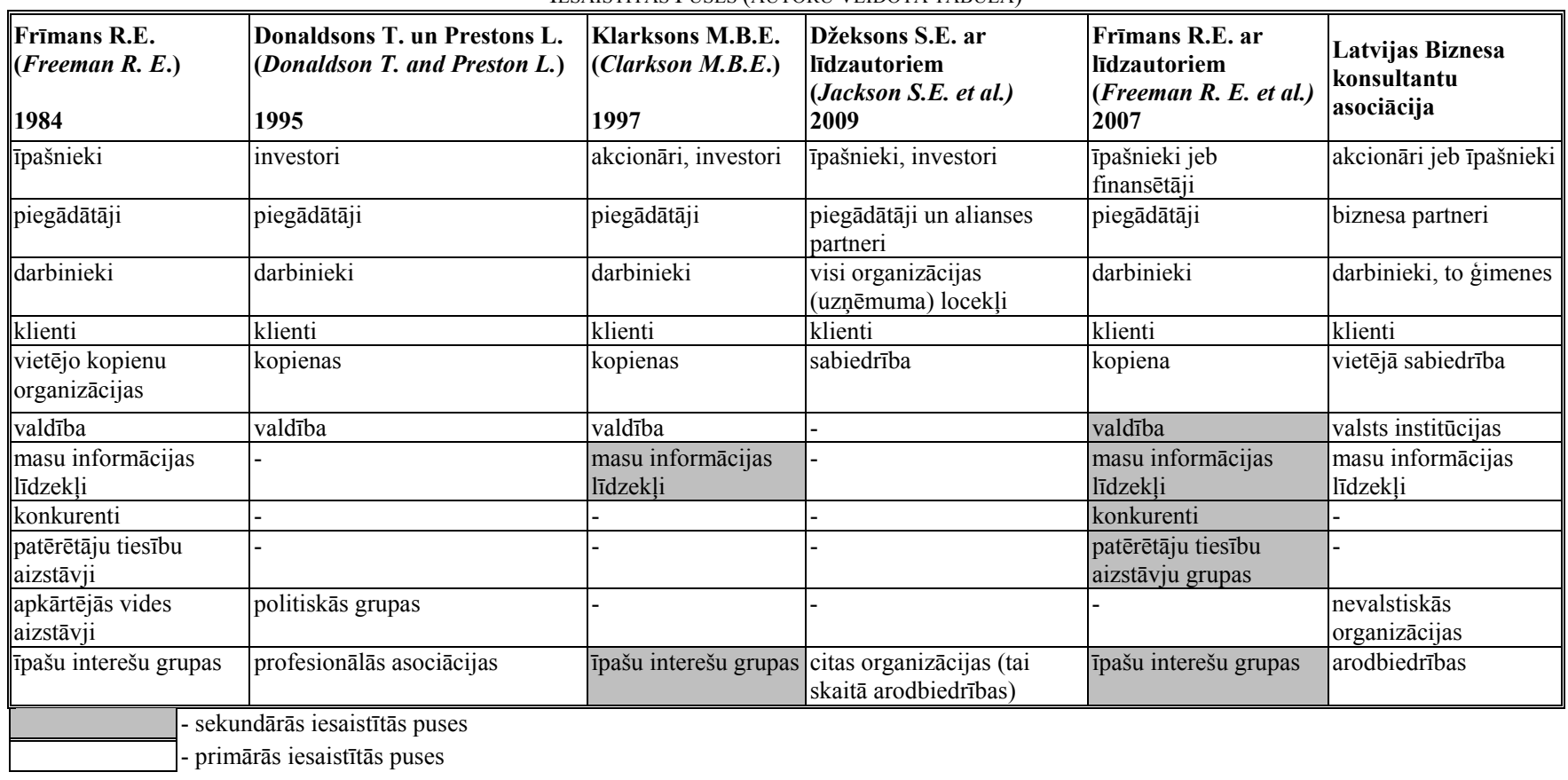

Publikācijās dominē uzskats, ka iesaistîtās puses tiek definētas saskaṇā ar to attiecībām ar organizāciju. Salīdzinot dažādu autoru viedokḷus par iesaistīto pušu teoriju, redzams, ka dal̦a autoru jēdzienu iesaistîtās puses lieto plašākā nozīmē, pieskaitot iesaistītajām pusēm ikvienu, kurš ietekmē vai var ietekmēt organizācijas mērķu sasniegšanu un kuru savukārt atgriezeniski ietekmē organizācijas darbība. Cita daļa autoru lieto šo jēdzienu šaurākā nozīmēe, runājot tikai par uzn̄ēmuma darbībā tieši iesaistītajām grupām. Tomēr visi jēdziena „iesaistītās puses” pētnieki min:

- īpašniekus, akcionārus vai investorus - citiem vārdiem ,naudas devējus”;

- darbiniekus;

- klientus, patērētājus;

- $\quad$ piegādātājus, biznesa partnerus;

- sabiedrību vai vietējās kopienas.

Katrai no iesaistītajām pusēm ir savas intereses attiecībā pret organizāciju.

Klienta vajadzības un intereses tiek apmierinātas, iegādājoties uzṇēmuma produktus vai pakalpojumus.
Klientiem ir svarīgi, lai uzñēmums spētu radīt noteiktas kvalitātes produktu, lai būtu augsta līmeņa apkalpošana un inovatīva produktu vai pakalpojumu attīstība. Klientus ietekmē uzṇēmuma darbība, un klienti, savukārt ir ieinteresēti uzṇēmuma darbībā. Ja prece vai pakalpojums būs pievilcīgs klientiem, tad uzṇēmums būs sev nodrošinājis ienākumus un ilgtspējīgu darbību.

Akcionāri un investori savukārt ir ieinteresēti, lai uzṇēmums strādātu ar pel̦nu - atdevi no pārdošanas, aktīviem un investīcijām, lai tam būtu laba reputācija un tas saglabātu savu konkurētspēju ilgtermiñā.

Darbinieki no uzṇēmuma sagaida taisn̄̄gu darba samaksu, kvalitatīvus un drošus darba apstākḷus, ilgtermiṇa nodarbinātību utt.

Dạ̦a autoru uzskata, ka visām iesaistītajām pusēm ir vienāda pozīcija attiecībā pret organizāciju, citi uzskata, ka dažādām iesaistītajām pusēm ir atšksirīgas attiecības ar organizāciju. Publikācijās atrodamas dažādas pieejas daudzveidīgo iesaistîto pušu klasificēšanai. Pieeju dažādība ir 
saistīta ar jautājumu: Cik daudz uzmanības katra iesaistītā puse ir pelnījusi vai cik daudz uzmanības tā pieprasa?

Nav iespējama situācija, ka visām organizācijas iesaistītajām pusēm ir vienādas intereses viṇu prasībās pret organizāciju. Bieži ir nepieciešams ņemt vērā potenciālos konfliktus, kurus var radīt šīs atšķirīgās intereses. Lai organizācija varētu veiksmīgi darboties arī ilgtermin̄ā, nepieciešams noteikt prioritātes attiecībā pret iesaistītajām pusēm. Pirmais solis ir identificēt organizācijas iesaistītās puses. Otrais solis - noteikt iesaistitto pušu prioritāti, balstoties uz noteiktām pazīmēm. Trešais solis - izstrādāt atbilstošu rīcības stratēǵiju.

Daļa autoru (piemēram, M.B.E. Klarksons, R.E. Frīmans u.c.) izdala divus iesaistīto pušu veidus: primārās un sekundārās iesaistītās puses. Visas piecas biežāk minētās grupas - klienti, darbinieki, piegādātāji, īpašnieki un sabiedrība - pieskaitāmas pie primārajām iesaistītajām pusēm.

G.T. Sevedžs (Savage G.T.) ar līdzautoriem iesaistītās puses identificē, ņemot vērā to prasības (angl̦u valodā claim) un spēju ietekmēt (angḷu valodā ability to influence), tādējādi nosakot, ka likumība jeb prasību (tiesību) pamatotība (angl̦ valodā legitimacy) un iedarbības jeb ietekmes spēks (angḷu valodā power) vērtējamas kā nozīmīgas pazīmes. Iedarbības spēks izriet no savstarpējās atkarības raksturojuma jeb saiknes ciešuma. Jo organizācija ir ciešāk saistīta ar kādu iesaistīto grupu, jo potenciāli spēcīgāka ir šī grupa. G.T. Sevedžs ar līdzautoriem iesaistîto pušu klasificēšanai izmanto divas pazīmes [14]:

1) potenciāls būt par draudu organizācijai;

2) potenciāls sadarboties ar organizāciju.

Šīs divas pazīmes lauj klasificēt iesaistītās puses četros tipos:

- atbalstošs (supportive);

- neatbalstošs (non-supportive);

- margināls jeb galējs (marginal);

- jaukts atbalsts (mixed blessing).

Tā kā katras š̄s grupas draudu un sadarbības pakāpe ir dažāda, autori paredz atšksirīgu organizācijas stratēǵiju attiecībās ar šiem iesaistīto pušu atšķirīgajiem tipiem.

Sadarbībā ar atbalstoš $\overline{\boldsymbol{a}}$ tipa iesaistītajām pusēm, kurām ir augsts sadarbības potenciāls, bet zems draudu potenciāls, atbilstoša ir iesaistī̌sanas stratēgija. Labi vadītā organizācijā vadītāji, darbinieki, mātes kompānijas, piegādātāji un bezpeḷnas sabiedriskās organizācijas ir atbalstošas iesaistītās puses. Neatbalstošās iesaistītās puses, kurām ir zems sadarbības potenciāls, bet augsts draudu potenciāls, vajadzētu atbalstīt vai aizstāvēt. Lielākām organizācijām neatbalstoši ir konkurenti, arodbiedrības, iespējams - pašvaldības un jauni masu informācijas līdzekḷi. Marginālās iesaistītās puses ar zemu draudu un sadarbības potenciālu ir jāvēro (jāmonitorē). Vidēji lielām organizācijām akcionāri, patērētāju interešu grupas un darbinieku profesionālās organizācijas ir marginālās iesaistītās puses. Jaukta atbalsta iesaistītajām pusēm ar augstu sadarbības un draudu potenciālu atbilstoša stratēgija ir sadarbība. Labi vadītās organizācijās pie š̄is grupas pieder darbinieki (uzņēmumam nozīmīgi darbinieki, kuru skaits ir nepietiekams), klienti vai patēēēāji un uzṇēmumi (kuru produkti vai pakalpojumi ir savstarpēji papildinoši). Š̄̄s iesaistītās puses spēlē ievērojamu lomu. Sadarbības rezultātā jaukta atbalsta iesaistītās puses var kḷūt gan par atbalstošām (ja pazeminās to draudu potenciāls), gan par neatbalstošām (ja pazeminās to sadarbības potenciāls) [14].

I. Kukule I. piedāvā iesaistītās puses klasificēt, pamatojoties uz to ietekmes spēku (power) un interesi, un pamatojoties uz šo dalījumu, pieņemt lēmumu par turpmāko rīcību [19]:

- iesaistītās puses ar zemu ieinteresētību un nelielu ietekmes spēku ir jāmonitorē (jāuzrauga);

- iesaistîtās puses ar zemu ieinteresētību, bet lielu ietekmi, ir jācenšas apmierināt;

- iesaistîtās puses ar lielu ieinteresētību, bet nelielu ietekmes spēku, ir jāinformē;

- iesaistîtās puses ar lielu ieinteresētību un lielu ietekmi ir uzman̄̄gi (closely) jāvada.

\section{TABULA}

MitČEla IESAistīTo PUŠU TIPOLOĢIJA (AUTORU VEIDOTA TABULA PĒC [11])

\begin{tabular}{|c|c|c|c|}
\hline $\begin{array}{l}\text { Iesaistītās puses } \\
\text { kategorija }\end{array}$ & $\begin{array}{l}\text { Iesaistītās } \\
\text { puses } \\
\text { nozīmīgums }\end{array}$ & $\begin{array}{l}\text { Kritēriji jeb } \\
\text { paz̄̄mes }\end{array}$ & $\begin{array}{l}\text { Iesaistītās puses } \\
\text { apakškategorija }\end{array}$ \\
\hline \multirow{3}{*}{$\begin{array}{l}\text { Slēptās iesaistītās } \\
\text { puses tikai ar } \\
\text { vienu no trim } \\
\text { paz̄̄mēm }\end{array}$} & \multirow{3}{*}{ zems } & $\begin{array}{l}\text { prasību } \\
\text { pamatotība }\end{array}$ & $\begin{array}{l}\text { patstāvīgās vai } \\
\text { diskrētās } \\
\text { iesaistītās puses }\end{array}$ \\
\hline & & ietekmes spēks & $\begin{array}{l}\text { potenciālās } \\
\text { iesaistītās puses }\end{array}$ \\
\hline & & $\begin{array}{l}\text { svarīgums un } \\
\text { steidzamība }\end{array}$ & $\begin{array}{l}\text { pieprasošās } \\
\text { iesaistītās puses }\end{array}$ \\
\hline \multirow{3}{*}{$\begin{array}{l}\text { Gaidošās } \\
\text { iesaistītās puses } \\
\text { ar divām no trim } \\
\text { pazīmēm }\end{array}$} & \multirow{3}{*}{ mērens } & $\begin{array}{l}\text { ietekmes spēks } \\
\text { un prasību } \\
\text { pamatotība }\end{array}$ & $\begin{array}{l}\text { dominējošās } \\
\text { iesaistītās puses }\end{array}$ \\
\hline & & $\begin{array}{l}\text { prasību } \\
\text { pamatotība un } \\
\text { svarīgums un } \\
\text { steidzamība }\end{array}$ & $\begin{array}{l}\text { atkarīgās } \\
\text { iesaistītās puses }\end{array}$ \\
\hline & & $\begin{array}{l}\text { ietekmes spēks } \\
\text { un svarīgums } \\
\text { un steidzamība }\end{array}$ & $\begin{array}{l}\text { bīstamās } \\
\text { iesaistītās puses }\end{array}$ \\
\hline $\begin{array}{l}\text { Definētās } \\
\text { iesaistītās puses } \\
\text { ar visām trim } \\
\text { pazīmēm }\end{array}$ & augsts & $\begin{array}{l}\text { ietekmes } \\
\text { spēks, prasību } \\
\text { pamatotība, } \\
\text { svarīgums un } \\
\text { steidzamība }\end{array}$ & - \\
\hline
\end{tabular}

R.K. Mitčels (Mitchell R.K.) ar līdzautoriem 1997.gadā izstrādāja iesaistīto pušu klasifikāciju, pamatojoties uz trim kritērijiem: prasību pamatotībai jeb likumībai (legitimacy) un iedarbības jeb ietekmes spēkam (power), pievienojot svarīgumu jeb steidzamību (urgency).

Katrai no iesaistītajām pusēm var atbilst viens vai divi, vai visi trīs no minētajiem kritērijiem, kā arī dažādas šo kritēriju kombinācijas [11]. Dažādas minēto kritēriju kombinācijas atbilstoši veido dažādas iesaistīto pušu kategorijas (sk. 2.tabula). Tādējādi š̄ klasifikācija paredz 7 iesaistīto pušu kategorijas.

Definētās iesaistītās puses, kurām raksturīgi visi trīs kritēriji, ir visnozīmīgākās, un to vajadzības tiks apmierinātas vispirms. Gaidošās iesaistītās puses, kas raksturojas ar diviem kritērijiem, ir vidēji nozīmīgas. Dominējošām iesaistītajām pusēm ir ietekmes spēks un prasību pamatotība. Sadarbībai ar 
šo grupu bieži tiek veidoti formāli mehānismi: uznēmuma pārvaldē piedalās arī ̄̄pašnieku pārstāvji, sadarbībai ar darbiniekiem tiek veidotas cilvēkresursu nodaļas u.c. Daļa autoru dominējošās iesaistītās puses uzskata par vienīgajām iesaistītajām pusēm.

Atšķirībā no G.T. Sevedža un līdzautoru izveidotās klasifikācijas, R.K. Mitčela un līdzautoru klasifikācija paredz arī atkarīgās iesaistītās puses, kurām ir svarīgas un steidzamas, kā arī pamatotas un likumīgas prasības, bet nav iespēju panākt savu prasību apmierinājumu. Šajā ziņā tās ir atkarīgas no organizācijas. Organizācijas attiecības ar atkarīgajām iesaistītajām pusēm ir nozīmīgas arī no sociālās atbildības viedokḷa. Šādas grupas iekl̦aušana parāda, ka iesaistīto pušu prioritāti nenosaka tikai to ietekmes uz organizāciju lielums un spēks, bet arī šo prasību pamatotība un steidzamība.

Viszemākais nozīmīgums ir slēptajām iesaistītajām pusēm, kurām ir tikai viens no kritērijiem. Patstāvīgajām iesaistītajām pusēm ir tikai viņu prasību pamatotība. Š̀ grupa ir Kerola filantropās jeb brīvprātīgās sociālās atbildības vai korporatīvās filantropijas mērkgrupa, jo tai nav ne ietekmes spēka, ne prasību steidzamības, lai panāktu savu mērķu sasniegšanu.

Sociāli atbildīga stratēgija jau ir kḷuvusi par daudzu konkurētspējīgu un ilgtspējīgu uzņēmumu neatñemamu ikdienas darbības sastāvdal̦u. Korporatīvās sociālās atbildības koncepcija paredz visu organizācijas iesaistīto pušu interešu ievērošanu. G.T. Sevedžs un līdzautori uzskata, ka uzn̄ēmumu vadītājiem nav tik būtiski censties apmierināt marginālo jeb galējo iesaistīto pušu vajadzības, bet gan maksimāli jācenšas apmierināt atbalstošo un jauktā atbalsta grupu vajadzības, tādējādi pastiprinot nākotnē viṇu atbalstu organizācijai. Taču ikvienas organizācijas resursi ir ierobežoti, un praksē organizācijas parasti pievērš uzmanību vinuprāt nozīmīgākajām iesaistītajām pusēm.

Iesaistīto pušu teorija ir cieši saistīta ar korporatīvās sociālās atbildības jēdzienu, kas tiek skatîts turpinājumā.

\section{KORPORATĪVĀ SOCIĀLĀ ATBILDĪBA (KSA)}

Korporatīvās sociālās atbildības (KSA) koncepcijai ir gara un daudzveidīga vēsture, kas sasaucas ar biznesa attīstību un sabiedrības vajadzību ievērošanu. Formāli šis jēdziens ir definēts 20.gs. otrajā pusē, taču KSA izpausmes cilvēkiem bija pazīstamas jau daudz senāk. Senās Mezopotāmijas karalis Hamurapi ap 1700.gadu pr.Kr. izveidoja kodeksu, saskaņā ar kuru celtnieki, viesnīcnieki vai zemnieki tika sodīti ar nāvi, ja vinuu nolaidība izraisīja kāda nāvi vai radīja nopietnas neērtības vietējiem iedzīvotājiem [22].

Par mūsdienu KSA izpratnes ēras sākumu uzskata 20.gs. 50.gadus. H.R. Bovens (Bowen H.R.) 1953.gadā izveidoja sākotnējo KSA definīciju biznesa vajadzībām. Bovens uzskatīja, ka KSA attiecas uz uzñēmēju pienākumu, ievērot tādu politiku, pieņemt tādus lēmumus vai sekot tādiem darbības virzieniem, kuri ir vēlami (pievilcīgi) sabiedrības mērķu un vērtību sasniegšanai. Viņaprāt, KSA nav panaceja, bet tā ietver sevī nozīmīgu patiesību, kura virzīs uzņēmējdarbību nākotnē [23].

Pēc M. Helda (Heald M.) domām, KSA ir uzṇēmuma izpratne par to, ka vadīšanas sastāvdal̦a ir pienākums strādāt (kalpot) ne tikai, lai panāktu maksimālus ekonomiskus sasniegumus, bet arī lai īstenotu humānu un konstruktīvu sociālo politiku [24].

K.Devisa (Davis K.) R. un Blomstroms (Blomstrom R.) 1966.gadā definēja, ka KSA ir personas pienākums ņemt vērā to, kādu ietekmi viṇa lēmumi un darbība atstāj uz kopējo sociālo sistēmu. Uzṇēmēji darbojas sociāli atbildīgi, ja viṇi ņem vērā to cilvēku vajadzības un intereses, kurus var ietekmēt konkrētā uzṇēmuma darbība. Tādā veidā viṇi redz tālāk par šauri ekonomiskām un tehniskām uzṇēmuma interesēm [23].

K.S. Voltone (Walton C.C.) 1967.gadā izveidoja fundamentālu sociālās atbildības definīciju. Viṇa raksta, ka jaunais sociālās atbildības koncepts ir uzñēmuma un sabiedrības ciešo savstarpējo attiecību apzināšanās un uzñēmuma augstākās vadības izpratne, ka uzṇēmums un iesaistītās grupas vēlēsies sasniegt katrs savus atbilstošos mērksus. Voltone akcentēja uzskatu, ka voluntārisms ir būtiska KSA sastāvdal̦a [23].

Attīstot šo uzskatu, H. Džonsons (Johnson H.) 1971.gadā rakstīja, ka sociāli atbildīgs ir uzṇēmums, kura vadītāji līdzsvaro daudzveidīgās intereses. Tā vietā, lai cīnītos tikai par lielu peḷnu saviem akcionāriem jeb īpašniekiem, atbildīgi uzñēmumi ņem vērā arī darbiniekus, piegādātājus, pilnvarotos pārstāvjus, vietējo sabiedrību un pat visu valsti, t.i., sociāli atbildīgi uzṇēmēji vai vadītāji interesējas ne tikai par uzñēmuma īpašnieku, bet arī citu uzn̦ēmuma dalībnieku un līdzpilsoṇu labklājību. Sociāli atbildīgu uzṇēmumu primārā motivācija ir lietderīguma maksimizēšana: uzṇēmums tiecas uz daudziem mērksiem tā vietā, lai censtos panākt maksimālu pel़u [23].

H.G. Fics (Fitch H.G.) 1976.gadā definē KSA sociālo problēmu kontekstā: ,, KSA ir nopietns mēǵinājums risināt tās sociālās problēmas, kuras pilnībā vai daḷeji ir izraisījuši paši uzn̄ēmumi ar savu darbību" [22].

Ā.B. Kerols (Carroll A.B.) 1979.gadā piedāvāja KSA definīciju: „Biznesa sociālā atbildība ietver ekonomiskas, tiesiskas, ètiskas un filantropiskas gaidas, ko sabiedrība sagaida no organizācijas noteiktā laika posmā”’ [25]. Pēc Ā.B. Kerola domām kopējā sociālā atbildība ietver četras sastāvdaļas: ekonomisko, tiesisko, ētisko un filantropisko atbildību.

P. Drakers (Druker P.) piedāvāja jaunu nozīmi (jēgu) KSA. Drakera pieejas novitāte ir ideja, ka biznesam vajadzētu „konvertēt” tā sociālo atbildību biznesa izdevīgumā. Tas nozīmē sociālas problēmas pārvēršanu ekonomiskā izdevīgumā un labumā, produktīvā ražīgumā, cilvēku kompetencē, labi apmaksātā darbā un bagātībā [25].

Piemērs par KSA sasaisti ar finansiālajiem sasniegumiem ir F. Kohrana (Cochran P.) un R.Vuda (Wood R.) pētījumi 1984. gadā. Kohrans un Vuds KSA mērīšanai iesaka izmantot reputācijas indeksu. M. Moskovita (Moskowitz M.) 1972.gadā izstrādātais indekss iedala uzñēmumus ,izcilos” (outstanding), „ar cildinošu atsauksmi” (honorable mention) un ,vissliktākajos” (worst) [27].

20.gs. 90.gados trīs teorijas saistībā ar KSA piesaistīja vislielāko uzman̄̄bu: korporatīvie sociālie sasniegumi (corporate social performance), biznesa ētika un iesaistīto pušu teorija [23].

1991.gadā Ā.B. Kerols piedāvāja četrus KSA elementus (ekonomisko, tiesisko, ētisko un filantropisko) apvienot 
piramīdā. „Protams, visi šie atbildības veidi zināmā mērā vienmēr pastāvēja, bet tikai pēdējos gados ètikas un filantropijas funkcijas ieņem ievērojamu vietu" [23]. Tai pašā laikā Ā.B. Kerols sasaista R.E. Frīmana iesaistīto pušu teoriju ar KSA jēdzienu. Iesaistīto teorija konkretizē sociālās atbildības jēdzienu, attēlojot specifiskas grupas vai personas, kuras organizācijām ir jāievēro savā korporatīvās sociālās atbildības pieejā un aktivitātēs [23].

M.Hopkins 1998.gadā definēja KSA saistībā ar iesaistītajām pusēm: „KSA ir saistīta ar ētisku vai sociāli atbildīgu izturēšanos pret uzṇēmuma iekšējām un ārējām iesaistītajām pusēm." Sociāli atbildīga uzvedība veicinās iesaistîto pušu attīstību [24].

G. Khūrijs (Khoury G.) ar līdzautoriem 1999.gadā KSA apraksta kā uzñēmuma vispārējas attiecības ar visām tā iesaistītajām pusēm - patērētājiem, darbiniekiem, sabiedrību, īpašniekiem/ investoriem, valdību, piegādātājiem, konkurentiem. Sociālās atbildības elementi ir investīcijas vietējās sabiedrības sasniegumos, attiecībās ar darbiniekiem, nodarbinātības radīšana un saglabāšana, vides pārvaldība un finansiāli sasniegumi [24].

Dž. Elkingtons (Elkington J.) 1997.gadā izveidoja slaveno konceptu „Triple Bottom Line”, kurš balstās uz trim pamatlietām (pamatjautājumiem): sociālā atbildība (cilvēki), atbildība par vidi (planēta), ekonomiskā atbildība (pel̦na). Tātad sociāli atbildīgiem uzņēmumiem ir jāṇem vērā ekonomiskā labklājība (uzplaukums), sociālā vienlīdzība un vides aizsardzība. Tas, kas ir labs videi un sabiedrībai, tas ir labs arī biznesa finansiālajiem sasniegumiem [24].

21.gs. KSA apskata arī kā ieguldījumu formu [28].

Saskan̄ā ar Eiropas Komisijas definīciju: KSA ir koncepcija, ar kuras palīdzību uzṇēmumi savā darbībā un aktivitātēs, kā arī sadarbībā ar iesaistītajām pusēm brīvprātīgi integrē sociālo un apkārtējās vides aspektu. Būt sociāli atbildīgam nozīmē ne tikai izpildīit tiesiskās prasības, bet arī ieguldīt „vairāk” cilvēku kapitālā, apkārtējās vides jautājumos un attiecībās ar iesaistītajām pusēm [29].

Piemēram, visiem labi zināmais uzņēmums Kellogg's varēja izdzīvot no 1906.gada līdz mūsdienām, jo sociālā atbildība ir uzñēmuma dzīvesveids [22]. Tad var secināt, ka KSA ir veids kā attīstît uzṇēmuma konkurētspēju un pagarināt uzñēmuma dzīves ciklu.

B. Longī (Lougee B.) un Dž. Vallas (Wallace J.), rakstot par KSA tendencēm, atzīmēja, ka KSA mudina uzṇēmumus noteikt to svarīgākās iesaistītās puses un ar to palīdzību uzņēmums cenšas „līdzsvarot” prioritātes un mērķus ar katru no šīm pusēm [30].

D. Minors (Minor D.) un Dž. Morgans (Morgan J.) atzīmēja saikni starp KSA stratēgiju un uzṇēmuma reputāciju, parādot KSA filozofiju mazliet no cita skatupunkta. Svarīgākas par ārēji redzamajām darbībām - „darīt labu” (no angḷu doing good), ir mazāk redzamās darbības - tātad „,nekaitējam” (no angḷ not doing harm) [31].

Citi ar KSA koncepciju cieši saistīti jēdzieni ir: sociālais un vides audits, iesaistīto pušu teorija, biznesa ētika, vides ilgtspēja, ilgtspējīga attīstība, ilgtspēja, stratēgiiskā filantropija, korporatīvā pārvaldība un stratēgiskā korporatīvā sociālā atbildība [22], [32], [33].
Apkopojot daudzveidīgos viedokl̦us par KSA būtību, S. Rahmans izdala 10 dimensijas, kas raksturo KSA [24]:

1. pienākums pret sabiedrību,

2. iesaistīto pušu iesaistī̌sana,

3. dzīves kvalitātes uzlabošana,

4. ekonomiskā attīstība,

5. êtiska biznesa prakse,

6. pakḷāvība likumam,

7. brīvprātība,

8. cilvēktiesības,

9. vides aizsardzība,

10. caurspīdīgums un atbildība.

Latvijā KSA jautājumi ir tikpat aktuāli kā citur pasaulē, pamazām tiem tiek pievērsta ar̄i aizvien lielāka uzmanība.

A. Pētersons un L. Pavāre uzskata, ka KSA ir laba biznesa prakse, kas demonstrē uzṇēmuma vērtības un principus un parāda, ka uzṇēmums brīvprātīgi ir iekḷāvis sociālās, vides un cilvēktiesību vērtības savā ikdienas darbībā un attiecībās ar darbiniekiem, klientiem, partneriem un vietējo sabiedrību [34].

Latvijas Biznesa konsultantu asociācija uzskata, ka KSA var saukt arī par uzņēmumu sociālo atbildību, turklāt šis jēdziens ir attiecināms uz visiem uzñēmumiem, ne tikai starptautiskiem globālā līmen̄̄ strādājošiem uzṇēmumiem. Būt sociāli atbildīgam uzņēmumam, viņuprāt, nozīmē ievērot visu cilvēku, organizāciju vai kopienu intereses, kuras var ietekmēt uzņēmuma darbību vai kuras ietekmē uzṇēmuma darbību. Korporatīiā sociālā atbildība ir tas, ko uzṇēmums dara un kā dara. KSA devīze: „Mums iet labi, jo mēs darām labu! ” („Doing Well by Doing Good”) [20].

Latvijas Darba devēju konfederācija KSA skaidro, kā brīvprātīgu rīcības filozofiju un uzṇēmējdarbības vērtību apliecinājumu sabiedrībai, veidojot attiecības starp uzņēmējiem, uzṇēmumiem un ietekmes auditorijām, kas ietver ilgtspējīgu attīstību un resursu saglabāšanu nākamajām paaudzēm [35]. Memorandu par KSA principiem Latvijā 2010.gadā parakstīja 22 organizācijas, kas pārstāv publisko, privāto un nevalstisko sektoru. Partneri vienojās par sadarbību KSA principu ieviešanā, pilnveidošanā un novērtēšanā. Balstoties uz Memorandā izvirzìto nepieciešamību novērtēt uzṇēmumu KSA progresu, LDDK sadarbībā ar Latvijas Brīvo arodbiedrību savienību, piesaistot ekspertus, izveidoja ilgtspējas indeksu.

Ilgtspējas indekss aptver 5 būtiskākos atbildīga biznesa faktorus: darba vide, apkārtējā vide, sabiedrība, tirgus attiecības, stratēgija. Balstoties uz minēto faktoru vērtējumu, uzņēmumi tiek sadalīti 4 grupās: platīna, zelta, sudraba un bronzas.

Latvijas uzṇēmumu Ilgtspējas indeksa metodologija ir balstita uz Dow Jones Sustainability Index un Business in the Community izstrādāto Corporate Responsibility Index, ñemot vērā arī ISO 26000 sociālās atbildības standarta un Globālās ziņošanas iniciatīvas (GRI) G3 vadlīnijas [36]. Latvijas Ilgtspējas indekss ir pielāgots, lai nodrošinātu uzņēmumu izvērtējumu atbilstoši Latvijas aktuālajiem ekonomiskajiem, sociālajiem un vides jautājumiem, vienlaikus gan saglabājot piesaisti starptautiski atzītiem korporatīvās atbildības un ilgtspējas kritērijiem.

Analizējot jēdziena KSA attīstību, var secināt, ka laika gaitā ir mainījusies šì jēdziena būtība. Ja sākotnēji ar korporatīvo sociālo atbildību saprata to cilvēku vajadzību un interešu 
ievērošanu, kurus var ietekmēt konkrētā uzṇēmuma darbība, tad vēlāk - 80.gados - uzskatīja, ka KSA ietver 4 sastāvdaḷas: ekonomisko, tiesisko, ētisko un filantropisko atbildību. 90.gados KSA saista ar ētisku un sociāli atbildīgu izturēšanos pret visām uzñēmuma iesaistītajām pusēm. 20.gs.beigās KSA jēdziens paplašinās ar atbildību par vidi. Tādējādi 21.gs.KSA pamatā ir sociālā atbildība, atbildība par vidi un ekonomiskā atbildība.

Jauns, augstāks domāšanas līmenis uzṇēmuma vadīšanā ir kopīgās vērtības radīšana, kur sociālā atbildība tiek integrēta kopējā uzṇēmuma stratēǵijā.

\section{V.KOPĪGĀS VĒRTĪBAS RADĪŠANA (KVR)}

Mainoties sabiedrībai, tās uzskatiem un vērtībām, mainās arī uzņēmumu vadības uzvedības un lēmumu pieņemšanas tendences, notiek uzṇēmumu stratēg̣iskās darbības filozofijas maiṇa. Jaunajā atbildīgas uzṇēmējdarbības ērā ir parādījies jauns jēdziens - „kopīgās vērtības radīšana” (KVR) no anglu valodas - Creating Shared Value (CSV).

2006.gadā M.E. Porters (Porter M.E.) un M.R. Krāmers (Kramer M.R.) izteica domu, ka kopīgās vērtības radīšana ir ceḷš uz korporatīvi sociālo integrāciju, kas pēc būtības ir KSA pieeja, balstīta uz savstarpēju saistību starp uzņēmuma veiksmīgu darbību un sociālo labklājību [37].

Vēlāk, 2011.gadā, rakstā „Creating Shared Value How to reinvent capitalism - and unleash a wave of innovation and growth" viņi aprakstīja sīkāk šo jauno pieeju uzṇēmuma stratēgijas veidošanai. Jēdzienu „kopīgā vērtība” var definēt kā uzṇēmuma dažādas politikas un reālās darbības, kas sekmē uzņēmuma konkurētspēju, vienlaicīgi attīstot un uzlabojot ekonomiskos un sociālos apstākḷus vidē, kurā šis uzṇēmums darbojas. Kopīgās vērtības radīšana fokusējas uz savstarpējo sakarību starp sociālo un ekonomisko progresu identificēšanu un attīstību [38].

Neskatoties uz to, ka KVR koncepciju akadēmiskajā vidē prezentēja tikai 2011. gadā, uzñēmums Nestlé to sāka ieviest savā darbībā, sākot jau no 2005.gada [38]. Uznēemums savu sociāli atbildīgo darbību dēvē par KVR stratēgiju, tātad uzñēmums rada vērtību sabiedrībai, kas vienlaikus ir līdzeklis vērtības radīšanai akcionāriem. KVR stratēǵija kḷva par svarīgāko elementu, stiprinot zīmolu un paaugstinot klientu lojalitāti [40].

Raksta autores sniedz šādu jēdziena KVR skaidrojumu: uzñēmuma ekonomiskās veiksmes pamatā ir sabiedrības kopējā attīstība, un tās aktualitāšu un problēmu risināšana faktiski rada ievērojamas iespējas organizācijas konkurētspējas uzlabošanai un vērtības radīšanai. Kop̄īās vērtības radīšana cieši sasaista uzṇēmuma sociālās aktivitātes ar tā mērksiem, padarot sociālo atbildību nevis par atsevišķu stratēgiju, bet gan integrējot to kopējā uzṇēmuma stratēǵijā kā neatñemamu tās sastāvdaļu [41].

Šis koncepts balstās uz kopīgas vērtības radīšanu abās uzṇēmuma vidēs - gan iekšējā, gan ārējā, un vēlams vairākos aspektos. Taču uzṇēmuma KVR aktivitātes visās sfērās nav pašmērķis vai prasība, mērķis ir radīt kopīgu vērtību - pat ja tikai vienā sfērā. Jomas, kurās uzṇēmums iesaistās KVR aktivitātēs, būs atkarīgas no uzṇēmuma un tā darbības virziena - vislabākie rezultāti tiks sasniegti, rīkojoties uzṇēmumam nozīmīgākajās sfērās, vai tajās, kurās uzṇēmums ir izcils.

Virzība uz īstermiņa sasniegumiem liek uzñēmumiem samazināt investīcijas sociālo vērtību radīšanā. Tādēḷ M.E. Porters un M.R. Krāmers iesaka kopīgās vērtības radīšanu, kura, tāpat kā pētījumi un attīstība, būtu uzskatāma par ilgtermiṇa ieguldījumu uzṇēmuma nākotnes konkurētspējā [37].

Salīdzinot KSA un KVR no dažādiem aspektiem, M.E. Porters un M.R. Kramers uzsver, ka KVR ir jauns līmenis kompānijas domāšanā.

KSA un KVR atšksirības skar dažādus aspektus. Pieci būtiskākie aspekti un pāreja no vienas pieejas uz otru tajos, ir atspogulota 2.attēlā. KSA vērtība "darīt labu" mainās uz KVR vērtību "ekonomisko un sociālo ieguvumu attiecība pret izmaksām”. KSA ideja par pilsonību, filantropiju un ilgtspējību pāriet uz nākamo līmeni - vienotas kompānijas un kopienas vērtības radīšanu. Var teikt, ka KVR ir labāk integrēta stratēǵija, jo tā iekļauj sevī ne tikai sociālus mērḳus, bet arī mērķi maksimizēt pel̦nu. KSA vairumā uzņēmumu ir kā atsevišşs projekts ar tam paredzētu budžetu, KVR ir integrēta uzñēmuma kopējā budžetā.

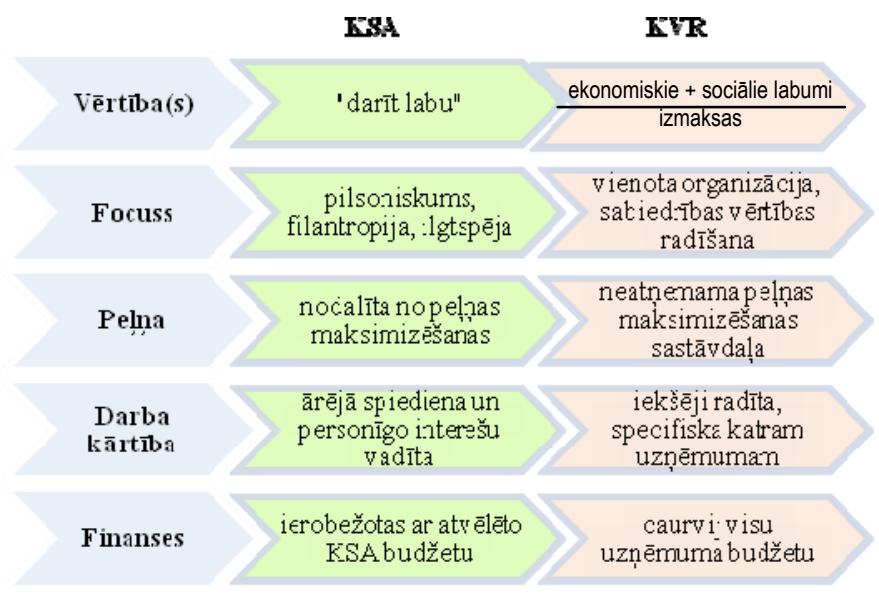

2. att. KSA pāreja uz KVR [40].

No investīciju viedokḷa M.R. Krāmers definēja KVR kā investīcijas uzṇēmējdarbības ilgtspējīgā konkurētspējā, kas vienlaikus uzrunā sociālos un vides mērkius.

Uzṇēmumi var radīit kopīgo vērtību trīs pamatveidos (virzienos) [38]:

1) pārdefinējot vērtību ķēdes - uzņēmumi var uzlabot izejvielu kvalitātes, daudzuma, izmaksu un uzticamības rādītājus un izejvielu izplatīšanu, vienlaicīgi darbojoties kā dabas resursu pārvaldnieki un veicinot ekonomisko un sociālo attīstību; galvenā uzmanība tiek pievērsta resursu un enerğijas lietošanai, loǵistikas efektivitātei, darbinieku produktivitātei, iekārtu un piegādes ķēdes atrašanas vietai;

2) pārskatot produktus un tirgu - uzñēmumi var apmierināt sociālās vajadzības, labāk kalpojot esošajiem tirgiem, piekḷūstot jaunajam, vai samazinot izdevumus, izmantojot inovācijas;

3) stiprinot attiecības ar vietējām grupām - uzṇēmumiem ir nepieciešami uzticami vietējie piegādātāji, funkcionējoša ceḷu 
un komunikāciju infrastruktūra, pieeja talantiem, kā arī efektīva un paredzama likumu sistēma.

Kā jau minēts, KVR ir jauns koncepts, tādēl šobrīd ir neliels zinātnisko publikāciju un pētījumu skaits par šo tēmu. Piemēram, M.A. Deniels (Daniel M.A.) un S. Sojamo (Sojamo $S$.) identificē iespējamas jaunas paradigmas uzñēmumiem, kas rada kopīgu vērtību visā to vērtību k̦ēdē [43].

KVR konceptā sabiedrības vajadzību apzināšana netiek uzskatīta par apgrūtinājumu un papildus izmaksu avotu, bet gan par uzn̄ēmējdarbības attīstības veidu, kas l̦auj vienlaikus radīt pievienoto vērtību arī sabiedrībai kopumā. Tādējādi, KVR ir veids, kā strādā uzṇēmums, kas sabiedrību un vidi uzskata nevis par apkārtējiem vai ārējiem apstākḷiem, kuros tas spiests darboties, bet gan par neatnemamu uzñēmējdarbības sastāvdal̦u. Centieni uzlabot un veicināt sabiedrības labklājību kḷūst par būtisku soli labāku biznesa rezultātu sasniegšanā.

\section{SECINĀJUM}

20.gs. 80. gados biznesa organizācijās notika fundamentālas, vētrainas un revolucionāras izmaiṇas. Mainījās attieksme pret organizācijā nodarbinātajiem cilvēkiem, atzīstot, ka darbinieki ir svarīgs organizācijas resurss cilvēkresurss un viena no primārajām iesaistītajām pusēm.

Izanalizējot jēdziena ,iesaistītās puses” populārākās definīcijas un klasifikācijas, autores secina, ka iesaistīto pušu un organizācijas savstarpējā ietekme gandrīz visos gadījumos ir abpusēja, atšksirības ir novērojamas tikai ietekmes ciešumā, intensitātē un svarīgumā. Korporatīvā sociālā atbildība ir tieši saistīta ar iesaistīto pušu teoriju. Katram uzņēmumam ir dažādas grupas, kuras tieši vai netieši ir iesaistītas uzņēmuma darbībā vai ieinteresētas uzñēmuma darbības rezultātos, piemēram: produktos (klienti), finanšu rādītājos (īpašnieki, akcionāri, investori) u.c.

Organizāciju ārējās iesaistītās puses pieprasīja korporatīivi sociāli atbildīgu rīcību. Š̄is izmaiņas atspoguļoja iesaistîto pušu gaidas un ietekmi uz organizācijas vadību. Līdz ar to mainījās arī vadības stratēǵija: ja tradicionāli vadības akcents ir vērsts uz organizācijas iekšējo vidi, tad jaunā pieeja paredzēja visu iesaistīto pušu - gan iekšējo, gan ārējo vadīšanu. Reālajā situācijā vadītāji koncentrējas uz attiecībām ar tām iesaistītajām pusēm, kurām ir kritiska nozīme organizācijas mērķu sasniegšanā.

Pretstatā uzskatam, ka vadītāji ir atbildīgi vien̄̄gi par pel̦nas gūšanu ekonomisko un tiesisko noteikumu ietvaros, vairāki pētnieki pierāda, ka organizācijām būtu jābūt sociāli atbildīgām un brīvprātīgi jāmeklē cel̦i, kā apmierināt to nozīmīgākās iesaistītās puses (key stakeholders).

Sociāli atbildīgas stratēgijas veidošanai un īstenošanai, lai uzñēmuma darbība būtu veiksmīga un ilgtspējīga, vispirms jau ir nepieciešams atpazīt, identificēt organizācijas iesaistītās puses. Nākamais solis ir veidot kvalitatīvas attiecības ar šīm ieinteresētajām pusēm - identificēt katras iesaistītās puses intereses un vajadzības, kā arī ar tām saistītos izaicinājumus, izvēlēties visoptimālāko sadarbības stratēgiju ar katru no iesaistītajām pusēm. Šāda stratēgija un tai sekojošās darbības nodrošinās iesaistīto pušu lojalitāti un uzṇēmuma efektīvu darbību, kas savukārt veicinās uzņēmuma ilgtspēju un konkurētspējas paaugstināšanos.
Ja nav atbilstoša rīcības modela, vadītāji tradicionāli cenšas „,ieellıot čîkstošos ritenuus” jeb vairāk uzmanības pievērš tām iesaistītajām pusēm, kuras aktīvi pieprasa savu interešu ievērošanu.

Sociāli atbildīgos uzñēmumos cilvēkresursu vadība un iesaistīto pušu interešu ievērošana ir vieni no stratēǵiski nozīmīgākajiem elementiem, kas ietekmē gan uzn̦ēmējdarbību kopumā, gan ilgtspējas mērķu sasniegšanu. Tādēḷ, īpaša pieeja uzñēmumam ir jāveido cilvēkresursu vadībai, lai to mainītu un piemērotu ilgtspējas principiem. Lai sasniegtu izvirzītos mērķus, uzñēmumam ir jāveido atbilstošs darbības plāns, jāizvēlas cilvēkresursu vadības modelis un metodes, jāizveido darbības rezultātu vērtēšanas kritēriju sistēma, jādefinē izmērāmi rezultāti.

Autores secina, ka strukturēta un apzināta iesaistīto pušu un cilvēkresursu vadība ir viens no faktoriem, kas veido organizāciju konkurētspējīgo priekšrocību.

Sociāli atbildīgas uzṇēmuma stratēǵijas īstenošana prasa no uzñēmuma, lai tas spētu atrast un ievērot līdzsvaru starp efektīvu, produktīvu un pel̦nu nesošu darbību un sociāli atbildīgu rīcību. Tādējādi cilvēkresursi kḷūst par vienu no svarīgākajiem uzn̄ēmuma resursiem jeb elementiem, kam jāfokusējas uz ilgtspējīgu nākotni.

Ir jāatzīmē, ka šobrīd Latvijā sociāli atbildīga stratēǵiskā pieeja parasti tiek realizēta vidējos un lielos uzņēmumos, kuru darbībā iesaistās daudzas un dažādas grupas. Līdz ar to uzņēmumiem ir nepieciešama arī īpaša, dažkārt unikāla, cilvēkresursu vadības politika, kas veicinātu uzņēmuma cilvēkresursu spēju izprast iesaistīto pušu nozīmīgumu un veidot kvalitatīvas attiecības ar tām.

\section{LITERATŪRAS SARAKSTS}

[1] G.A. Cole, Personnel Management. 4th ed., Theory and practice. London: DP Publications Ltd, 1997. 410 p.

[2] G. Dāvidsone, Organizāciju efektivitātes modelis. Rīga: O.D.A., 2008. 328 lpp.

[3] M. Armstrong, A Handbook of Human Resource Management Practice. 10th ed. London: Kogan Page, 2006. 982 p.

[4] P. M. Wright, G. C. McMahan, A. McWilliams, Human Resources and Sustained Competitive Advantage: A Recourse-Based Perspective. International Journal of Human Resource Management, 1994, vol. 5, N. 2, p. 301-326. http://dx.doi.org/10.1080/09585199400000020

[5] L.R. Gomez-Meija, D.B. Balkin, R.L. Cardy, Managing Human Resources. 5th ed. Upper Saddle River, New Jersey: Person Prentice Hall, 2007. $672 \mathrm{p}$.

[6] A. Price, Human Resource Management. 4th ed. South-Western: Cengage Learning EMEA, 2011. $640 \mathrm{p}$.

[7] S. Snell, G. Bohlander, Managing Human resources. 16th ed. SouthWestern: Cengage Learning, 2011.832 p.

[8] L.R. Dombrovska, Cilvēkresursu kapitāla vadība. Teorija un prakse, Rīga: Zvaigzne ABC, 2009. 212 lpp.

[9] I. Vorončuka, Personāla vadība. Rīga: Latvijas Universitāte, 2009. 400 lpp.

[10] I. Ešenvalde, Personāla praktiskā vadība, Rīga: Merkurijs LAT, 2004. 308 lpp.

[11] R.K. Mitchell, B.R.Age, D.J. Wood, Toward a Theory of Stakeholder Identification and salience: Defining the Principle of Who and What Really Counts. Academy of Management Review, 1997, vol. 22, N 4, p. 853-886. http://dx.doi.org/10.2307/259247

[12] http://dx.doi.org/10.5465/AMR.1997.9711022105

[13] R. E. Freeman, Strategic management: A stakeholder approach. Boston: Pitman, 1984. 276 p.

[14] G.T. Savage, T.W. Nix, C.J. Whitehead and J.D. Blair, „Strategies for assesing and managing organizational stakeholders," Academy of Management Executive, vol. 5 no. 2, pp. 61-75, 1991. 
[15] T. Donaldson, L. E. Preston, The stakeholder Theory of the Corporation: Concepts, Evidence, and Implications. Academy of Management Review, 1995, vol 20, N 1, p.65-91. http://dx.doi.org/10.2307/258888 http://dx.doi.org/10.5465/AMR.1995.9503271994

[16] M.B.E. Clarkson, A Stakeholder Framework for Analyzing and Evaluating Corporate Social Performance. Academy of Management Review, 1995, vol. 20, N 1, p. 92-117.

[17] S. E. Jackson, R. S. Schuler, S. Werner, Managing Human Resources. 11th ed. New York: South-Western, Cengage Learning, 2009. 696 p.

[18] R.E. Freeman, J.S. Harrison, A.C. Wicks, Managing for Staheholders: Survival, Reputation and Success. New Haven: Yale University Press, 2007. $179 \mathrm{p}$.

[19] Ietekmes pušu vadība-iespējas un izaicinājumi. I. Kukule. [tiešsaiste]. SlideShare, 2012- [skatīts 21.08.2012.]. Pieejams: www.slideshare.net/.

[20] Kas ir korporatīvā sociālā atbildība un kādi ir ieguvumi? LBKA [tiešsaiste]. Riga : Biznesam.lv, 2010- [skatits 20.11.2012.]. Pieejams: http://www.biznesam.lv/?sub=publications\&id=126.

[21] Ilgtspējìgums, mūsu saistības. CEMEX Latvia. [tiešsaiste]. Riga CEMEX S.A.B. de C.V., 2012- [skatits 21.08.2012.]. Pieejams: www.cemex.lv/su/su oc.asp.

[22] J. J. Asongu, The History of Corporate Social Responsibility. Journal of Business and Public Policy, 2007, vol. 1, N 2, p. 842-859. http://dx.doi.org/10.1177/000765039903800303

[23] A.B. Carrol, Corporate Social Responsibility, Evaluation of the Definitional Construct. Business \& Society, 1999, vol. 38, N 3, p. 268 295.

[24] S. Rahmann, Evaluation of Definitions: Ten Dimensions of Corporate Social Responsibility. World Review of Business Research, 2011, vol. 1, N 1, p.166-176. http://dx.doi.org/10.5465/AMR.1979.4498296 http://dx.doi.org/10.2307/257850

[25] A.B. Carroll, A Three-Dimensional Conceptual Model of Corporate Performance. Academy of Management Review, 1979, vol.4, N 4, p. 497505. http://dx.doi.org/10.2307/41165066

[26] P.F. Drucker, The new meaning of corporate social responsability. California Management Review, 1984, vol. 26, N 2, p. 53-63. http://dx.doi.org/10.2307/255956

[27] F. Cochran, R. Wood, Corporate Social responsibility and Financial Performance. Academy of Management Journal, 1984, vol. 27, N 1, p. 42-56. http://dx.doi.org/10.2307/259398 http://dx.doi.org/10.5465/AMR.2001.4011987

[28] A. McWilliams, D. Siegel, Corporate Social Responsibility: A Theory of the Firm Perspective. The Academy of Management Review, 2001, vol. 26, N 1, p. 117-127.

[29] Promoting a European framework for corporate social responsibility. Green Paper, European Commission Directorate-General for Employment and Social Affairs. [tiešsaiste]. Brisele : EC, 2001- [skatīts 01.04.2012.]. Pieejams: http://eurlex.europa.eu/LexUriServ/site/en/com/2001/com2001_0366en01.pdf. http://dx.doi.org/10.1111/j.1745-6622.2008.00172.x

[30] Lougee, B., Wallace, J. The Corporate Social Responsibility (CSR) Trend. Journal of APPLIED CORPORATE FINANCE, 2008, vol. 20, N 1, p. $96-108$. http://dx.doi.org/10.1525/cmr.2011.53.3.40

[31] D. Minor, J. Morgan, CSR as Reputation Insurance: PRIMUM NON NOCERE. California Management Review, 2011, vol. 53, N 3, p. 4059.

[32] A. Crane, D. Matten, Business Ethics. 3rd ed. NY: Oxford University Press, 2010. 592 p. http://dx.doi.org/10.1002/job.380

[33] D. E. Rupp, J.Ganapathi, R. V., et al. Aguilera, Employee reactions to corporate social responsibility: an organizational justice framework Journal of Organizational Behaviour, 2006, vol. 27, Nr. 1, p. 537-543.

[34]. A. Pētersons, L. Pavāre, Korporatīvā sociālā atbild̄̄ba. Rīga: Biznesa augstskola Turïba, 2005. 192 lpp.

[35] Korporatīiās sociālās atbildības platforma [tiešsaiste]. Rīga : Latvijas Darba devēju konfederācijas mājas lapa, 2006 - [skatîts 21.11.2012.]. Pieejams: www.lddk.lv./index.php?c=226
[36] Ilgtspējas Indekss. [tiešsaiste]. Riga : Ilgtspējas Indekss, 2010-2012[skatîts 27.10.2012.]. Pieejams: http://www.ilgtspejasindekss.lv/.

[37] M. E. Porter, M. R. Kramer, Strategy and Society The Link Between Competitive Advantage and Corporate Social Responsibility. Harvard Business Review, 2006, vol. 84, N 12, p. 78-92.

[38] M. E. Porter, M. R. Kramer, Creating Shared Value How to reinvent capitalism - and unleash a wave of innovation and growth. Harvard Business Review, 2011, N 1, p. 62-77.

[39] Creating Shared Value: A How-to Guide for the New Corporate (R)evolution. V. Bockstette, M. Stamp. [tiešsaiste]. FSG, 2011- [skatîts 23.01.2012.].

Pieejams:

http://www.fsg.org/tabid/191/ArticleId/351/Default.aspx?srpush=true. http://dx.doi.org/10.1596/1020-797X-10 210

[40]N. Christiansen, Creating Shared Value through Basic Business Strategy. Development Outreach, 2008, vol. 1, N 6, p. 10-12.

[41] I. Lapina, I. Borkus, O. Starineca, Corporate Social Responsibility and Creating Shared Value: Case of Latvia. Scientia Special Journal Issues, 2012, vol. 68, N 339, p. 1886-1892.

[42] Creating Shared Value: Making the Case in Your Company, A conversation with: Mark Kramer, Founder and Managing Director, FSG, Marc Pfitzer, Managing Director, FSG, Paul Ellingstad, Health Director, Office of Global Social Innovation, HP, Jessica Hubbard (formerly Stannard-Friel), Senior Manager Corporate, Social Responsibility, Houghton Mifflin Harcourt, Paul Snyder, Vice President Corporate Responsibility, InterContinental Hotels Group. M. Kramer, M. Pfitzer. [tiešsaiste]. FSG, 2011- [skatîts 21.11.2012.]. Pieejams:

http://www.fsg.org/Portals/0/Uploads/Documents/PDF/HP CSV webi nar_presentation.pdf?cpgn $=$ Webinar\%20DL $\% 20$ \%20CSV\%20Making\%20the\%20Case\%20Webinar\%20ppt.

[43]M. A. Daniel, S. Sojamo, From risks to shared value? Corporate strategies in building a global water accounting and disclosure regime. Water Alternatives, 2012, vol 5, N 3, p. 636-657.

Inga Lapina Dr.oec., Associate Professor, working at Faculty of Engineering Economics and Management of Riga Technical University since 1997. In 2011 she joined the Institute for Quality Engineering at Riga Technical University as an Acting Head of the Department of Quality Technology. Working as an expert of Evaluation Commission at Higher Education Quality Evaluation Centre in Latvia. Area of research interests: quality management, business ethics and corporate social responsibility, macroeconomics and development of human capital.

E-mail: Inga.Lapina@rtu.lv

Gunta Maurāne Mg.biol, Docent, working in Faculty of Engineering Economics and Management of Riga Technical University since 1991. She had been working at research laboratory of Scientific Organization of Work (SOW) on problems of psychophysiological base from the year 1978 till 1991. Area of research interests: human resource management, ergonomics.

E-mail: Gunta.Maurane@rtu.lv

Olga Stariṇeca has obtained a Social Sciences Bachelor (B.sc.oec.) degree in management from Riga Technical University, Latvia in 2011 and is currently continuing her studies at Riga Technical University to gain the degree of Master of Social Sciences (M.sc.oec.) in Management.

From 2010 until July 2011 she was Vice-President of External Relations and Manager of Sales Department at the Riga chapter of the non-government organisation AIESEC in Latvia. Currently she is a Mentor and Sales Trainer at the Riga chapter of AIESEC in Latvia. From March till August 2012 she held internship position with European Commission, Department of HR and Security, conducting research on ethics issues in public sector. Her research interests lay with human resources management issues.

E-mail: Olga.Starineca@rtu.lv

\section{Inga Lapiṇa, Gunta Maurāne, Olga Stariṇeca. Stakeholders and Human Resource Management: Socially Responsible Strategy}

The goal of the research is to describe theoretical aspects of following concepts: stakeholders, staff, human resources and social responsibility; in order to analyse and evaluate the commonalities and differences of these concepts. Several research methods, such as analysis and synthesis of scientific literature, logical and comparative analysis were applied. Based on theoretical research and empirical analysis, authors provide a summary of concept development and own understanding of the concepts as part of socially responsible business strategy or approach to creating shared value. Identification and analysis of the current situation is based on scientific papers, books and results of scientific research. Analysing the most popular definitions and classifications of the concept 
$2013 / 24$

"stakeholders", authors conclude that interaction of stakeholders and organization is mutual in almost all cases with differences observed only in terms of impact closeness, intensity and importance. To develop a socially responsible strategy companies should identify their stakeholders and their interests, and find the optimal cooperation strategy for each stakeholder. Implementing such strategy will yield stakeholder loyalty, efficient long-term performance of the company and additional competitive advantage. When implementing socially responsible strategy, the company needs to balance productive performance and socially responsible activities. Therefore, human resources become one of the key resources in a company that is focused on sustainable development. However, it should be pointed out that social responsibility in Latvia is mainly part of strategies of medium and large companies that have multiple stakeholders. Companies have to foster development of their human resources' ability to establish and maintain suitable relationships with stakeholders.

Инга Лапиня, Гунта Мауране, Ольга Старинец. Заинтересованные стороны и управление человеческими ресурсами: социально ответственная стратегия

Целью исследования является характеристика теоретических аспектов терминов: заинтересованные стороны, персонал, человеческие ресурсы, социальная ответственность, чтобы проанализировать и оценить общие и различающиеся компоненты данных понятий. Для реализации исследования были использованы различные методы, такие как анализ и синтез научной литературы, логический и сравнительный анализ. На основании теоретических исследований и эмпирического анализа авторы предоставляют обобщение развития терминов и своё понимание терминов, реализуя социально ответственную бизнес-стратегию или подход создания общей ценности. Научные работы, книги и результаты исследований предоставили информацию для ретроспективного анализа и идентификация текущей ситуации. Анализируя самые популярные определения и классификации термина "заинтересованные стороны", авторы приходят к выводу, что взаимодействие заинтересованных сторон и организации практически во всех случаях является двусторонним, различия наблюдаются только в плотности воздействия, интенсивности и значимости. Для создания социально ответственной стратегии необходимо идентифицировать заинтересованные стороны предприятия и их интересы и выбрать самую оптимальную стратегию сотрудничества с каждой из заинтересованных сторон. Реализация разработанной стратегии обеспечит лояльность заинтересованных сторон, долгосрочную эффективную деятельность предприятия и повышение его конкурентоспособности. В случае реализации социально ответственной стратегии компании необходимо найти баланс между продуктивной работой и социально ответственными действиями. Таким образом, человеческие ресурсы становятся одним из самых значимым ресурсов предприятия, который нацелен на устойчивое (долгосрочное) развитие. Тем не менее, следует отметить, что реализация социально ответственной стратегии в Латвии осуществляются в основном в крупных и средних компаниях, которые имеют много заинтересованных сторон. Предприятия должны способствовать развитию способностей человеческих ресурсов, создавать и поддерживать соответствующие отношения с заинтересованными сторонами. 